\title{
バージ船から投入された捨石の 沈降・堆積挙動に関する数値シミュレーション
}

\author{
三井 順1 ・田中 真史 2 ・山崎 真史 ${ }^{3}$ ・原 隆 4 \\ 1 正会員 （株）不動テトラ 総合技術研究所（テ300-0006 茨城県土浦市東中貫町 2-7） \\ E-mail: jun.mitsui@fudotetra.co.jp \\ 2 正会員（株）不動テトラ 土木事業本部技術部（†103-0016 東京都中央区日本橋小網町 7-2） \\ 3 (株) 不動テトラ 土木事業本部技術部（广103-0016 東京都中央区日本橋小網町 7-2） \\ 4 (株) 不動テトラ土木事業本部営業部（テ103-0016 東京都中央区日本橋小網町 7-2）
}

\begin{abstract}
流体解析と DEM 解析の連成計算に基づき，バージから投入された捨石の沈降・堆積過程を精度良くか つ短時間に予測するシミュレーション方法を構築した。本手法では石を球形状の粒子として扱うが，抗力 係数の修正や新たな揚力モデルの導入により，不規則な形状を有する石材の流体力特性を再現することが できる．また，粒子の転がり抵抗を考慮することにより，堆積時の安息角についても再現可能である．さ らに，堆積した 1 投分毎に粒子群を面で置き換える処理をすることにより，計算時間が大幅に短縮可能と なる．本計算手法の妥当性については，石材の水中沈降特性やバージから投入した際の堆積形状等につい て模型実験と比較することにより確認した。
\end{abstract}

Key Words : fluid-particle interaction, artificial upwelling mound, settlement, accumulation, OpenFOAM, CFDEM

\section{1. はじめに}

大水深海域に設置される人工湧昇流マウンドは，船底 全開式の土運船（以下，バージという）から捨石等を直 接投入して築造するのが一般的である. 効率的な施工の ためには，捨石マウンドの堆積形状を精度良く予測する ことが必要となる.

捨石の沈降・堆積過程においては, 沈降する捨石群と 流体との相互作用や，着底時の個々の捨石の接触・衝突 を考慮することが重要であると考えられる. それらを直 接扱うことのできる解析手法として, 流体解析と個別要 素法（DEM）を連成させる手法が挙げられる．例えば， 小田ら ${ }^{1)}$ はMAC法により粒子を含む流れを密度流的に解 く流体計算手法とDEMとを連成させる手法を開発した. 重松ら ${ }^{2)}$ はこれを発展させて3次元の計算モデルを開発 し，従来の鉛直2次元計算との比較を行っている. また， 原田ら ${ }^{3)}$ や鶴田ら ${ }^{4)}$ は，流体の計算格子スケールが粒子ス ケールよりも小さい高解像度型の固液混相流解析により 粒子周りの流れ場の詳細な検討を行っている. しかし, 何れの研究においても粒子形状は球あるいは円として扱 われるため, 不規則な形状を有する石材に適用する場合, 沈降時の流体力特性や堆積時の安息角などの再現性に課 題が残る．また，このような数值計算手法は，沈降時の
粒子の散乱過程を確率論的に予測するモデル（例えば松 見 $5^{5)}$ ) 等と比較して計算時間が長いため, 実務への適 用においては計算時間の短縮も課題となる.

そこで本研究では, 流体解析とDEMの連成計算に基づ く手法における上記の課題を解決し, 高精度かつ実用的 なシミュレーション方法を構築し, 模型実験との比較に よりその妥当性を検証した.

\section{2. 模型実験方法}

石単体の水中沈降速度や水平移動量の分布（バラツキ） を調べるための単体沈降実験と，バージからの投入を想 定した群体沈降実験を実施した。いずれも縮尺は $1 / 80$ と し，フルードの相似則が成り立つものとした.

\section{(1) 捨石の諸元}

捨石の質量は $2.0 \mathrm{~g}$ 内外/個（現地量で $1 \mathrm{t}$ 内外/個）とし, 砕石をふるいにかけて所定の質量範囲となるように選別 した. 実験で用いた捨石の質量加積曲線を図-1に示す. 四中には後述する数值計算での分布も併記している. 数 值解析では実験で得られた分布を近似するように5種類 の径の粒子を混合した。実験で用いた捨石の密度は平均 


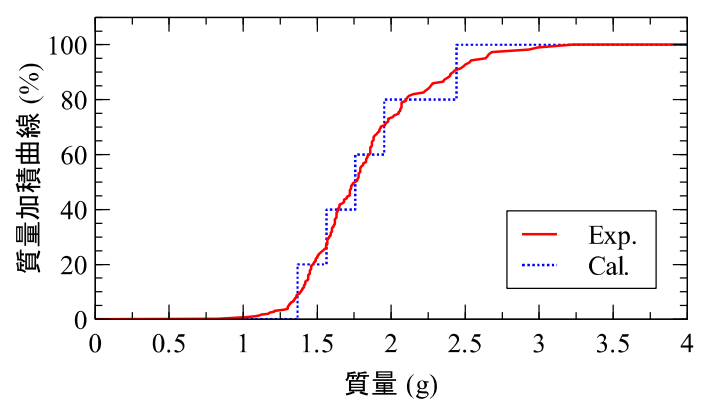

図-1 捨石の質量加積曲線
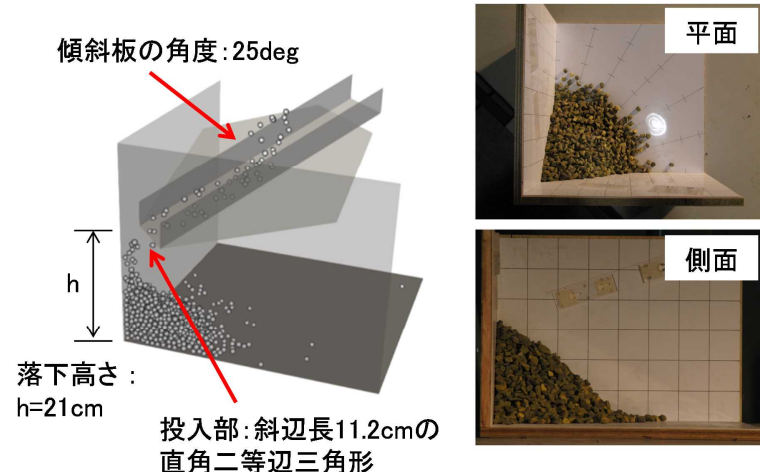

図-2＼cjkstart安息角の実験装置の模式図と実験状況

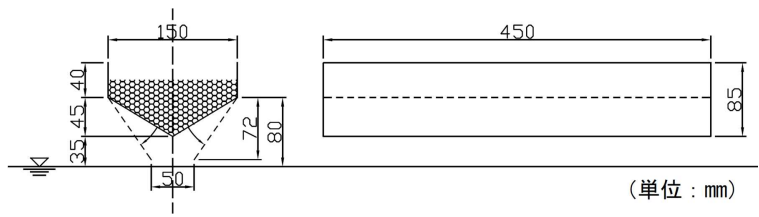

図-3 バージ模型の形状

$2.65 \mathrm{~g} / \mathrm{cm}^{3}$ であり, 数值計算でも同じ值とした.

気中での安息角を堀口らの゙同様の方法により測定し た．実験装置の模式図と実験状況を図-2に示す．使用す る石の大きさの違いを考慮して, 堀口らの実験装置を 1.4 倍にスケールアップしたものを使用した. 実験は3回繰り 返し行い，得られた安息角の平均值は35.1度であった。

\section{（2）単体沈降実験}

実験には長さ $1.0 \mathrm{~m}$, 幅 $1.0 \mathrm{~m}$, 高さ $2.3 \mathrm{~m}$ のアクリル水 槽を使用した．水深は2.0 mとし，無作為に選んだ109個 の石を1つずつ水面から静かに落下させた. 沈降状況を直 角2方向からデジタルビデオカメラで撮影し, 画像から石 の座標を読夕取り, 沈降速度や水平方向の移動量（バラ ツキ）を求めた。 実験結果は, 数值計算における流体力 モデルのキャリブレーションに用いており，次章で述心゙ る.

\section{（3）群体沈降実験}

バージ模型の形状を図-3に示す. 1投あたりの捨石の投 入量は $2540 \mathrm{~cm}^{3}$ (現地量で $1300 \mathrm{~m}^{3}$ ) とした. 投入に要す る時間が沈降・堆積挙動に影響することが知られている ため (例えば，五明ら ${ }^{7)}$ )，投入時間 $T_{0}$ を $3.4 \mathrm{~s}, 6.7 \mathrm{~s}, 10.1 \mathrm{~s}$

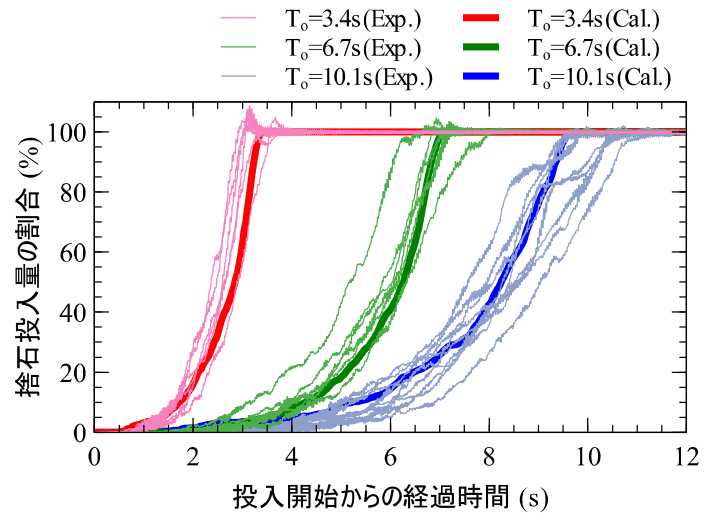

図-4 捨石投入量の時間変化

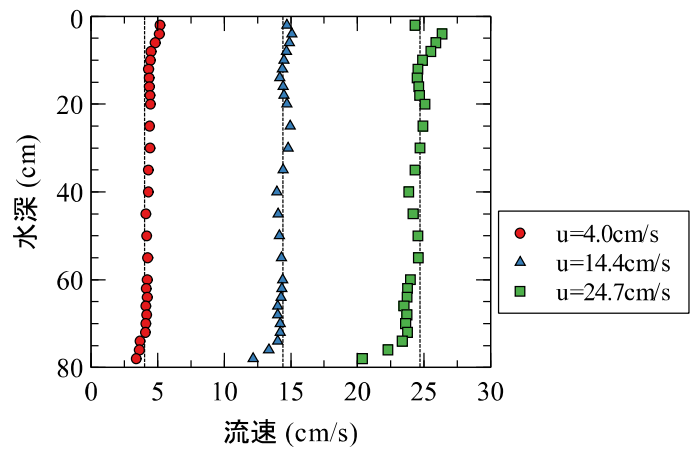

図-5＼cjkstart定常流中実験における流速分布

(現地量で30 s, 60 s, $90 \mathrm{~s}$ ) の3種類に設定した. 投入開始 からの経過時間と投入量の関係を事前に測定した結果を 図-4に示す。バージの開扉速度は一定となるよう留意し たが，実験の繰り返し毎に若干のバラツキを有する。ま た図中には後述する数值計算における結果も併せて示し ている. 数值計算では実験での投入量の平均的な経時変 化に合うように開扉速度を調節した。

群体沈降実験は，静水中において同一地点から複数回 投入して堆積形状を調べるための実験と，定常流中にお いて投入し，流れによる影響を確認するための実験の2 種類を実施した.

静水中での群体沈降実験では，単体沈降実験と同じア クリル水槽を使用した. 水深は $1.0 \mathrm{~m}, 1.4 \mathrm{~m}, 1.8 \mathrm{~m}$ の3種類， 投入時間は前述の3 種類に設定した. 投入回数は 10 回ない し12回とし，投入位置および船の向きは一定とした．投 入後にレーザー距離計により堆積高を測定した。

定常流中での実験では，還流装置を有する断面水路を 用いた．水路幅は $0.5 \mathrm{~m}$ ，水深は $0.8 \mathrm{~m}$ とした 水平流速 を4.0 cm/s, $14.4 \mathrm{~cm} / \mathrm{s}, 24.7 \mathrm{~cm} / \mathrm{s}$ (それぞれ現地量で 0.36 , $1.29,2.21 \mathrm{~m} / \mathrm{s}$ ) の3種類，投入時間は前述の3種類に設定 した．流速分布は図-5に示すように鈆直方向に概ね一様 な分布となるようにした．沈降状況を水路側方からデジ タルビデオカメラで撮影するとともに，堆積後の状況を 写真撮影した。群体沈降実験の結果については，数值計 算結果と併せて後述する. 


\section{3. 数値計算方法}

\section{(1) 概要}

計算にはオープンソースの粒子・流体連成解析プログ ラムである， $\mathrm{CFDEM}^{8)}$ (version 3.8.0)を用いた。これは， 流体解析プログラムのOpenFOAM ${ }^{9}$ と，DEM解析プログ ラムのLIGGGHTS ${ }^{10)}$ を連成させるものである.

DEMにおいては個々の粒子の並進・回転の運動方程式 (式(1)および式(2)）を解き, 粒子間接触力や流体力を考 慮する.

$$
\begin{gathered}
m \ddot{\mathbf{x}}=\mathbf{F}_{n}+\mathbf{F}_{t}+\mathbf{F}_{f}+\mathbf{F}_{b} \\
\mathbf{I} \frac{d \boldsymbol{\omega}}{d t}=\mathbf{r}_{c} \times \mathbf{F}_{t}+\mathbf{T}_{r}
\end{gathered}
$$

ここに， $m$ は粒子の質量， I は慣性モーメント， $\mathbf{x}$ は位 置, $\omega$ は角速度, $\mathbf{r}_{c}$ は粒子半径, $\mathbf{F}_{n}$ および $\mathbf{F}_{t}$ はそれぞれ 法線方向および接線方向の粒子間接触力, $\mathbf{F}_{f}$ は流体力, $\mathbf{F}_{b}$ は重力, $\mathbf{T}_{r}$ は転がり抵抗によるトルクである. 流体力 としては, 抗力, 揚力, 圧力勾配による力, 粘性力, 浮 力を考慮する. 抗力と揚力については後述する.

一方，流体解析においては，基礎方程式として以下に 示すvolume-averaged Navier-Stokes方程式を解き, 空隙率

(液相の体積率) の影響や, 粒子から受ける運動量を考 慮する.

$$
\frac{\partial \alpha_{f}}{\partial t}+\nabla \cdot\left(\alpha_{f} \mathbf{u}_{f}\right)=0
$$

$\frac{\partial\left(\alpha_{f} \mathbf{u}_{f}\right)}{\partial t}+\nabla \cdot\left(\alpha_{f} \mathbf{u}_{f} \mathbf{u}_{f}\right)=-\alpha_{f} \nabla \frac{p}{\rho_{f}}-\mathbf{R}_{p f}+\nabla \cdot \boldsymbol{\tau}$

ここに， $\alpha_{f}$ は空隙率， $\mathbf{u}_{f}$ は流速， $p$ は圧力， $\rho_{f}$ は密度, $\tau$ は粘性応力テンソル, $\mathbf{R}_{p f}$ は粒子相との運動量交換を表 す. 乱流モデルには標準 $k$-£モデルを用いた.

流体解析の計算格子サイズは5 cmとした. 粒子径は $d_{50}=1.08 \mathrm{~cm}$ であるため, 粒子径の約5倍となる. DEMと流 体解析の計算時間刻みはそれぞれ1/9000 s，1/90sであり， DEMの100ステップ後に1度流体計算を進め, その際に結 果の受け渡しが行われる. 流体計算とDEM計算の連成計 算状況の例を図-6に示す.

\section{（2）流体力モデルの改良}

既往の研究と同様に，本計算手法においても粒子は球 形状として扱われるが，不規則な形状を有する石材に作 用する抗力や揚力を再現するため, 以下のように流体力 モデルの改良を行った.

まず，粒子に作用する抗力 $\mathbf{F}_{D}$ はDi Felice ${ }^{11)}$ のデルを ベースとした. Di Feliceのモデルは, 次式に示すように 抗力係数 $C_{D}$ を粒子単体の抗力係数 $C_{D 0}$ と空隙率の影響に 関する係数との積で表したモデルである.

$$
\begin{gathered}
\mathbf{F}_{D}=\frac{C_{D} \pi \rho_{f} d_{p}^{2}}{8}\left|\mathbf{u}_{f}-\mathbf{v}\right|\left(\mathbf{u}_{f}-\mathbf{v}\right) \\
C_{D}=C_{D 0} \alpha_{f}^{2-\chi} \\
\chi=3.7-0.65 \exp \left[-\left(1.5-\log _{10} R e_{p}\right)^{2} / 2\right] \\
C_{D 0}=\left(0.63+4.8 / \operatorname{Re}_{p}^{0.5}\right)^{2} \\
\operatorname{Re}_{p}=\alpha_{f} d_{p}\left|\mathbf{u}_{f}-\mathbf{v}\right| / \nu_{f}
\end{gathered}
$$

ここに， $d_{p}$ は粒子径， $\mathbf{v}$ は粒子速度， $v_{f}$ は動粘性係数, $R e_{p}$ は粒子レイノルズ数である. $C_{D 0}$ は元のモデルでは球 の抗力係数が用いられている (式(8)) が, 本研究では石 単体の水中沈降速度の実験結果に基づき, 次式のように 修正した。

$$
C_{D 0}=1.3
$$

高橋ら ${ }^{12)}$ の実験によると, 石材の抗力係数は実物と模型 とで顕著な違いが認められていない. 従って, 本研究で は粒子レイノルズ数によらず $C_{D 0}$ を一定值とした. 図-7 は式(6)により求まる抗力係数 $C_{D}$ を図示したものである. 空隙率が大きいほど抗力係数は小さくなる傾向であり, 単体の抗力係数 $(=1.3)$ に近づいていく.

次に，粒子に作用する揚力について検討を行った．実 際の石材には，その形状や流れに対する向きに応じて， 流れに直交する方向に揚力が作用する. そのため, 球形 状の場合よりも沈降時の分散は大きくなると考えられる.

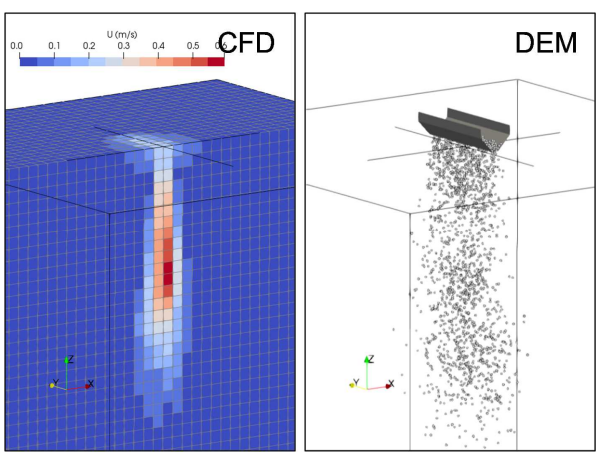

図-6 連成計算状況例

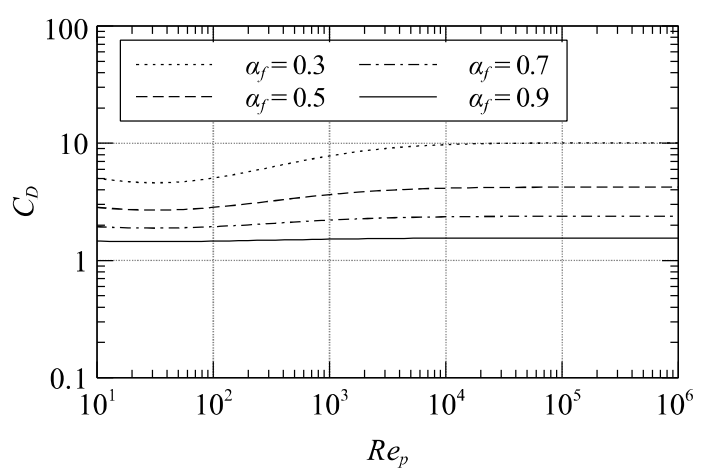

図-7 抗力係数 
揚力

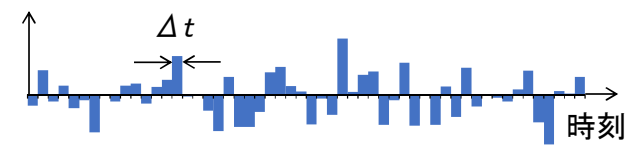

図-8 揚力モデルの模式図

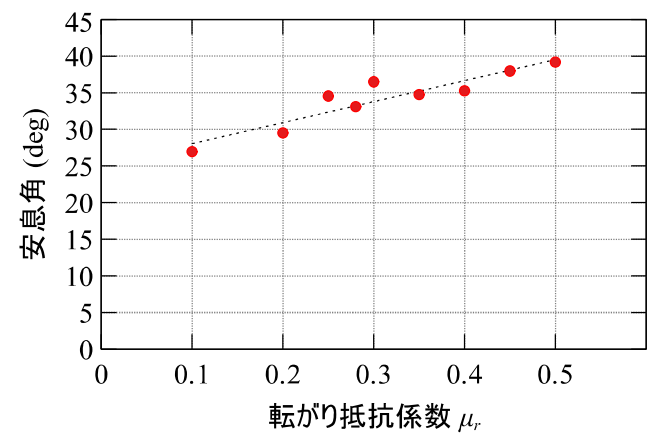

図-9 転がり抵抗係数と安息角の関係（計算結果）

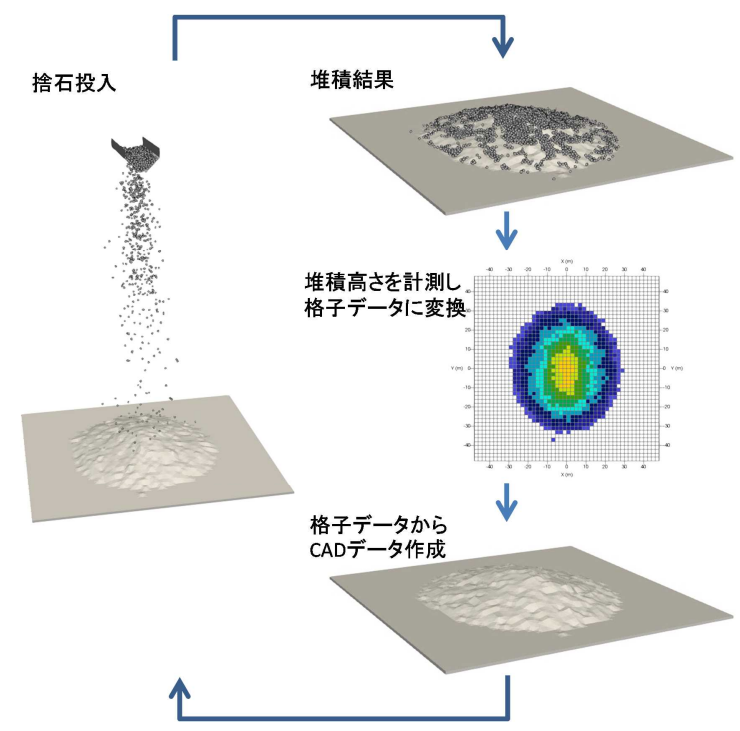

図-10 複数回投入時のマウンド表面の処理方法

そこで, 抗力作用方向と直交する2方向にランダムな揚力 を作用させることとした．揚力の各方向成分の大きさは 平均が 0 , 標準偏差が $\sigma_{L}$ の正規乱数とし, 流体計算の計 算時間刻み $\Delta t(=1 / 90 \mathrm{~s})$ ごとに乱数を発生して揚力を作用 させた（図-8）。ここで， $\sigma_{L}$ は抗力の大きさに比例する と仮定し, その比例係数は単体沈降実験における分散状 況を再現するように，以下のように定めた.

$$
\sigma_{L}=1.05\left|F_{D}\right|
$$

\section{（3）転がり抵抗モデルによる安息角の再現}

堆積時における石の安息角を再現するために, Iwashita and Oda ${ }^{13}$ による転がり抵抗モデルを適用した. このモデ ルは接触する粒子に対して，転がりに抵抗する付加的な トルクを与えるものである. その転がり抵抗係数を決定
土木学会論文集B3 (海洋開発), Vol. 76, No. 2, I_504-I_509, 2020.

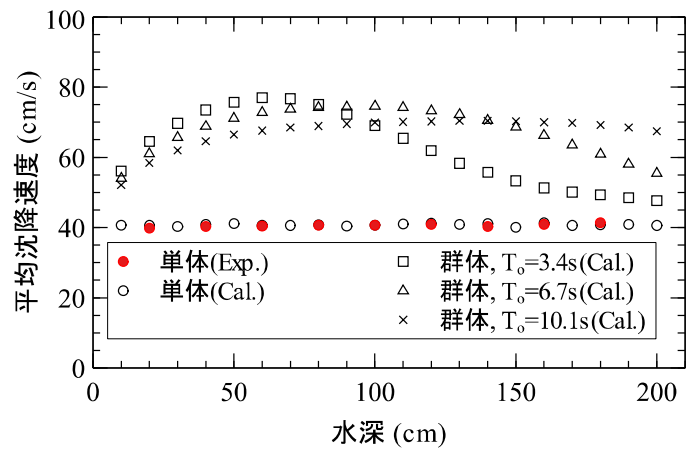

図-11 捨石の水中沈降速度

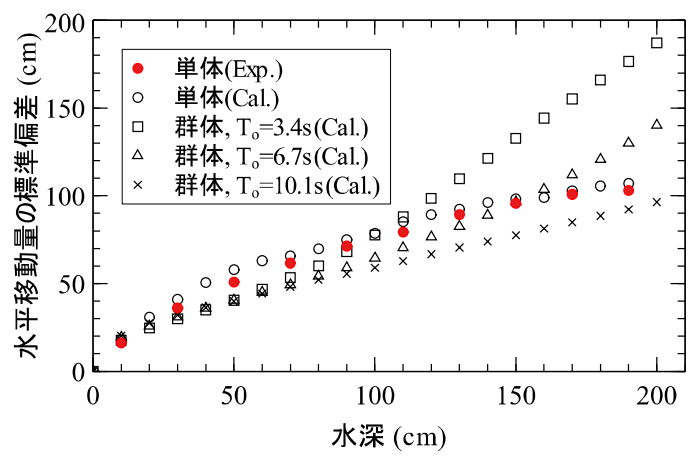

図-12 沈降時水平移動量の標淮偏差

するために, 気中での安息角の測定実験をDEM解析で再 現した. 図-9は，DEM解析によって得られた転がり抵抗 係数と安息角の関係であり，実験で得られた安息角 $\left(=35.1^{\circ}\right)$ と一致するように粒子間の転がり抵抗係数を 0.35 と定めた.

また，マウンド全体の築造をシミュレーションする等 により粒子の数が膨大となる場合, 計算時間が非常に長 くなってしまう問題があった. そこで, 図-10に示すよう に堆積した粒子群を1投分毎に面で置き換えることとし た. 置き換えたマウンド表面と粒子との転がり抵抗係数 についても，実験結果との適合性を見て 0.4 と定めた.

\section{4. 数值計算結果}

\section{（1） 水中沈降特性}

静水中における単体および群体の沈降実験を数值解 析で再現し, 沈降特性を調べた. 単体の計算では粒子数 200個, 群体の計算では投入1回分 (粒子数2168個)のデー 夕について, 沈降速度と水平移動量の標準偏差を調べた。

図-11は単体および群体で投入した際の, アンサンブル 平均沈降速度の鉛直方向変化を示したものである．単体 の結果について計算值と実験值を比較すると，両者は良 く一致していることが確認できる，単体の場合は，ほぼ 一定速度で沈降しており，落下開始直後に終末速度に到 達していることがわかる。一方, 群体で沈降する場合は, 連行する流れの影響により沈降速度は最大で単体の場合 

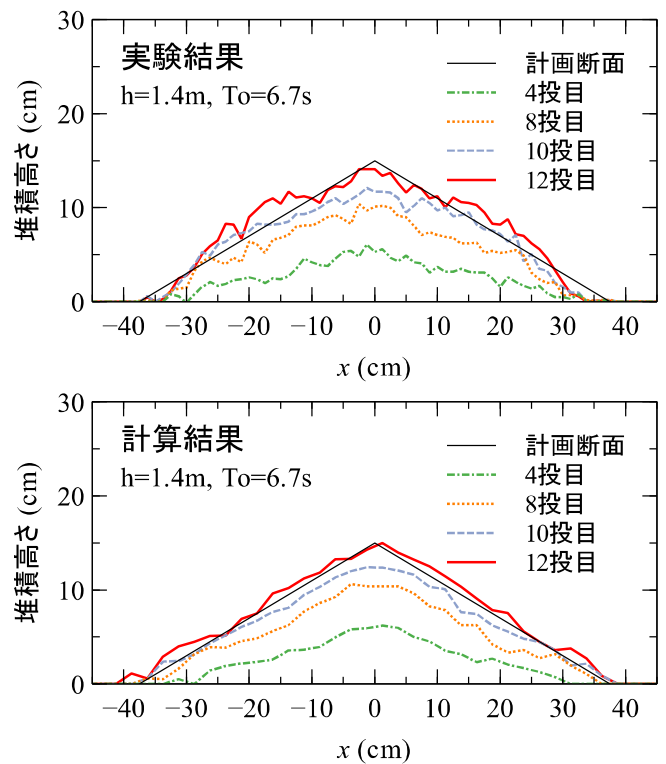

図-13 複数回投入時の堆積断面形状（投入回数ごと）
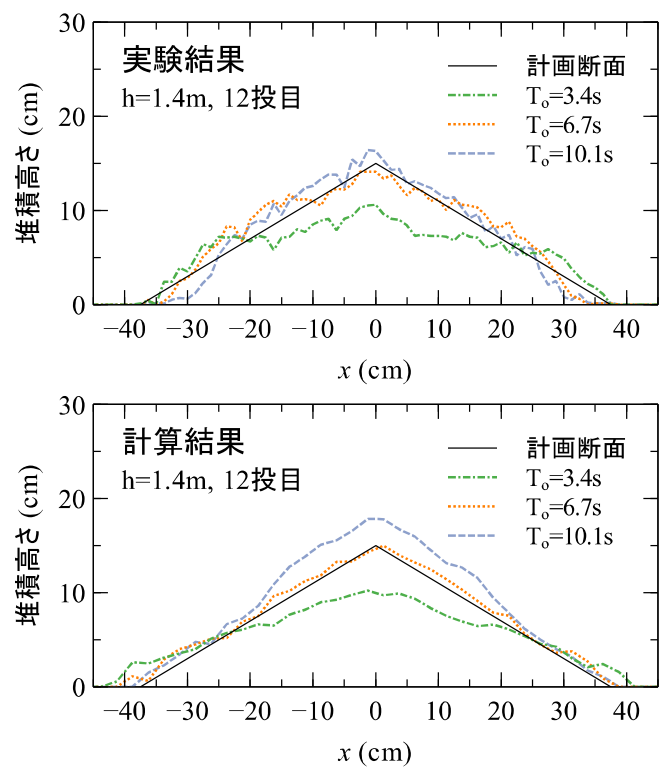

図-14 投入時間別の堆積断面形状

の2倍程度まで大きくなる. また，水深の増加に伴い，投 入時間による差異が明確に確認できる．群体での実験に ついては，個々の石の沈降速度を画像から読み取るのは 困難であるため実験值は得られていないが，単体での沈 降特性を適切に再現することで，計算手法の信頼性は確 保できていると考えた.

次に, 水平移動量の標準偏差を図-12に示寸. 単体の計 算結果は実験值と良く一致していることが確認できる. 単体で沈降する場合, 移動量の標準偏差は水深の平方根 に概ね比例して大きくなる，一方，群体で沈降する場合 は，水深の増加に対して概ね直線的に大きくなるようで ある. 投入時間による違いは水深が深くなるにつれて大 きく現れており，投入時間が短いほど沈降時の分散が大 きくなることがわかる。このように，群体の沈降特性は
土木学会論文集B3 (海洋開発), Vol. 76, No. 2, I_504-I_509, 2020.
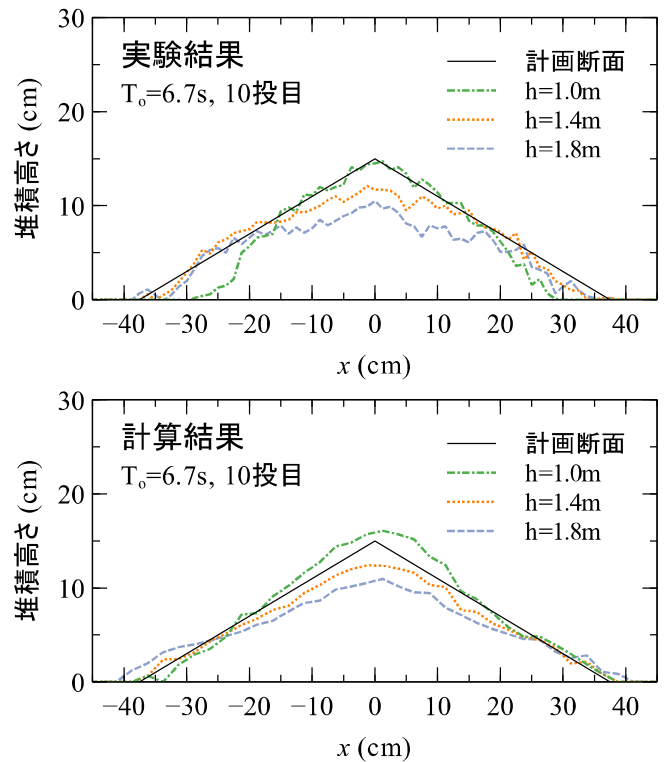

図-15＼cjkstart設置水深別の堆積断面形状

沈降時に生じる連行流の影響等により複雑となる。しか しながら，本手法によればそのような影響を考慮した予 測が可能となる.

\section{（2）複数回投入時の堆積特性}

計算手法の妥当性を確認寸るため，静水中において バージ模型から複数回投入した際の，船の向きに対して 直交方向の堆積断面形状を実験結果と比較した。ここで は，頂点の高さ $15 \mathrm{~cm}$ ，法面勾配1:2.5の断面を計画断面と 想定した. まず，水深 $h=1.4 \mathrm{~m}$ ，投入時間 $T_{0}=6.7 \mathrm{~s} の$ 条件 で投入回数ごとの堆積断面形状を比較したものを図-13 に示す．計算結果は，投入回数ごとの堆積高さや法面勾 配等の実験結果の特徴を良く再現していることがわかる。 次に，投入時間を変化させたケースの結果を図-14に，設 置水深を変化させたケースの結果を図-15に示す．図-12 からわかるように，投入時間が短くなるほど，また，設 置水深が深くなるほど沈降時の粒子の分散が大きくなる ため，堆積勾配は緩やかになる，計算結果はこのような 投入時間の違いや設置水深の違いによる影響を適切に再 現できていることがわかる.

\section{（3）流れ場における沈降・堆積状況}

次に，定常流中での群体沈降実験の状況を数值計算で 再現して，流れによる影響を確認した．図-16は流速 $u=$ $24.7 \mathrm{~cm}$, 投入時間 $T_{0}=10.1 \mathrm{~s} の$ 条件における沈降・堆積状 況を比較したものである. 沈降時の分散の状況や流れに よる平均的な移動量について，概ね再現できていること がわかる。

現地での施工においては，投入前に流速分布を測定し， 流れの影響を考慮して投入位置を補正する必要がある. 本計算手法を用いれば，設置水深や捨石の諸元，バージ 

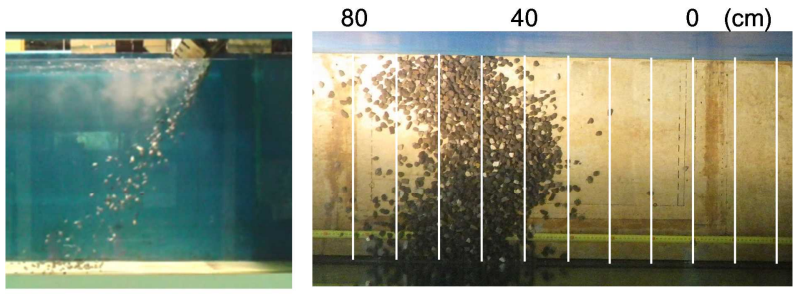

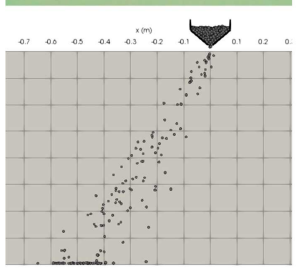

(a) 沈降状況

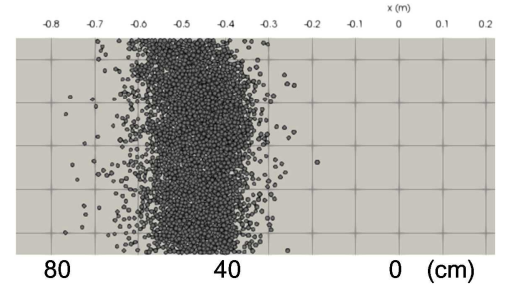

(b) 堆積状況 図-16＼cjkstart定常流中における沈降・堆積状況の比較

の開屝時間などの条件を考慮して，流速に応じた投入位 置の補正量を求めることができる.

\section{5. おわりに}

流体解析とDEM解析の連成計算に基づき, バージから 投入された捨石の沈降・堆積過程を予測するシミュレー ション方法を構築した. 従来手法においては，DEMにお ける粒子形状は球や円として扱われていたため，不規則 な形状を有寸る石材に適用寸る際の流体力や安息角の再 現性に課題があったが，本解析手法では，粒子の転がり 抵抗を考慮するほか，新たな揚力モデルを導入するなど 流体力モデルを改良することにより，石の形状に特有の 流体力特性や安息角を再現でき，沈降・堆積過程を高精 度に予測可能である.

また，計算に要する時間は，一般的なスペックのパソ コンで1投あたり 30 分程度であるため, 人工湧昇流マウン ド全体の築造シミュレーションも現実的な時間で実施可 能である.

\section{参考文献}

1) 小田一紀，重松孝昌，大西伸幸：DEMAC 法による粒 子群の分散・堆積挙動のパラメトリック解析, 海岸工 学論文集, Vol.40, pp.951-955, 1993.

2) 重松孝昌, 小田一紀, 田野雅彦, 廣瀬真由: 個別要素 法による水中沈降粒子群の 3 次元挙動に関する研究, 海岸工学論文集, Vol.47, pp.996-1000， 2000.

3) 原田英治, 後藤仁志, 鶴田修己 : 固液混相乱流モデル の捨石群の沈降・堆積過程計算への適用例, 土木学会 論文集 B，Vol.66，No.1，pp.25-34，2010.

4) 鶴田修己，原田英治，後藤仁志 : 粒子流 LES による 粒子群の非定常沈降過程の解析, 土木学会論文集 B2 (海岸工学), Vol.67, No.2, pp.I_736-I_740, 2011.

5) 松見吉晴, 岸口孝文: 捨石マウンド築造時のバージ船 の配船位置について, 海岸工学論文集, Vol.37, pp.769-773, 1990.

6) 堀口俊行, 涉谷一, 香月智, 田附正文: 集合体要素の 形状特性が安息角に及ぼす影響に関する解析的検討, 構造工学論文集, Vol.57A, pp.136-146, 2011.

7) 五明美智男, 松田信彦, 浅沼丈夫, 関根信寛 : 人工湧 昇流マウンド造成のための捨石投入の管理と最適化, 海洋開発論文集，Vol.23，pp.381-386， 2007.

8) Goniva, C., Kloss, C., Deen, N.G., Kuipers, J.A.M. and Pirker, S. : Influence of rolling friction on single spout fluidized bed simulations, Particuology, 10(5), 582-591, 2012.

9) OpenFOAM : https://openfoam.org/, 参照 2020-03-29.

10) Kloss, C., Goniva, C., Hager, A., Amberger, S. and Pirker, S. : Models, algorithms and validation for opensource DEM and CFD-DEM, Progress in Computational Fluid Dynamics, An Int. J., 12(2-3), 140-152, 2012.

11) Di Felice, R. : The voidage function for fluid-particle interaction systems, Int. J. Multiph. Flow, 20(1), 153-159, 1994.

12）高橋英俊, 近藤基, 小岩苔生, 岩崎峯夫, 白鳥保夫, 菊谷徹, 佐藤義博, 斎藤勝, 松本茂: 捨石の水中落下 速度について，港湾技研資料，No.249，1976.

13) Iwashita, K. and Oda, M. : Rolling resistance at contacts in simulation of shear band development by DEM, J. Eng. Mech., 124(3), 285-292, 1998.

(Received February 6, 2020)

(Accepted May 1, 2020)

\title{
NUMERICAL SIMULATION ON SETTLEMENT AND ACCUMULATION OF STONES DUMPED FROM SPLIT BARGE
}

\author{
Jun MITSUI, Masashi TANAKA, Shinji YAMAZAKI and Takashi HARA
}

A simulation method has been developed to predict the settlement and accumulation process of rubble from a barge with high accuracy and in a short time, based on the coupled CFD-DEM analysis. Although this method treats the stones as spherical particles, by modifying the drag coefficient and introducing a new lift model, the hydrodynamic properties of the irregularly shaped stones are reproduced. The angle of repose during accumulation is also reproduced by taking into account the rolling resistance of the particles. In addition, the computation time can be significantly reduced by replacing the accumulated particles with planes for each discharge. The validity of this analysis method was confirmed by comparing the settling behavior and the shape of accumulation with the model experiment. 